Boston University School of Law

Scholarly Commons at Boston University School of Law

Faculty Scholarship

8-12-2016

\title{
By Any Other Name: Rational Basis Inquiry and the Federal Government's Fiduciary Duty of Care
}

Gary S. Lawson

Boston Univeristy School of Law

Follow this and additional works at: https://scholarship.law.bu.edu/faculty_scholarship

Part of the Constitutional Law Commons

\section{Recommended Citation}

Gary S. Lawson, By Any Other Name: Rational Basis Inquiry and the Federal Government's Fiduciary Duty of Care , in No. 16-29 Boston University School of Law, Public Law Research Paper (2016).

Available at: https://scholarship.law.bu.edu/faculty_scholarship/368

This Article is brought to you for free and open access by Scholarly Commons at Boston University School of Law. It has been accepted for inclusion in Faculty Scholarship by an authorized administrator of Scholarly Commons at Boston University School of Law. For more information, please contact lawlessa@bu.edu. 


\title{
BU School of Law
}

\section{BY ANY OTHER NAME: RATIONAL BASIS INQUIRY AND THE FEDERAL GOVERNMENT'S FIDUCIARY DUTY OF CARE}

\author{
Boston University School of Law \\ Public Law \& Legal Theory Working Paper No. 16-29
}

August 12, 2016

Gary Lawson

Boston University School of Law

Guy I. Seidman

The IDC Herzliya, Israel

This paper can be downloaded without charge at:

http://www.bu.edu/law/faculty-scholarship/working-paper-series/ 


\title{
BY ANY OTHER NAME:
}

\section{RATIONAL BASIS INQUIRY AND THE FEDERAL GOVERNMENT’s FIDUCIARY DUTY OF CARE}

\author{
Gary Lawson*
}

Guy I. Seidman**

\begin{abstract}
Under modern law, federal legislation is subject to "rational basis review" under the doctrinal rubric of "substantive due process." That construction of the Fifth Amendment's Due Process Clause is notoriously difficult to justify as a matter of original constitutional meaning. Something very similar to substantive due process, however, is easily justifiable as a matter of original constitutional meaning once one understands that the Constitution, for interpretative purposes, is best seen as a kind of fiduciary instrument. Fiduciary instruments operate against a background of legal norms that notably include a duty of care on the part of agents. All federal actors under the Constitution exercise delegated authority (from "We the People") as agents, and thus all federal actors under the Constitution are bound by a duty of care. This duty has much affinity with the business judgment rule of corporate law, in that the scope of the duty of federal actors, as gleaned from eighteenth-century agency and corporate law, probably does not exceed avoidance of gross negligence. Building on a forthcoming book entitled " 'A Great Power of Attorney': Understanding the Fiduciary Constitution," which demonstrates in depth the fiduciary character of the Constitution, this article examines the contours of the duty of care that forms part of the background of every constitutional grant of power.
\end{abstract}

Suppose that you execute a power of attorney giving other people authority over a portion of your affairs, such as management of some of your assets or control over your health-care decisions. Or suppose that you yourself are made the guardian of your ailing grandparent through such a document. How would you expect the designated agents in these scenarios to carry out their tasks? How would the law expect them (or you) to do so?

The law's answer is probably very close to most people’s intuitions: A power of attorney creates a principal/agent, or fiduciary, relationship in which the agent exercising delegated 
authority is bound to act in accordance with the direct instructions of the principal and, in the absence of such direct instructions, must abide by a set of default fiduciary obligations to the principal, such as a duty to exercise personal judgment, a duty of loyalty to the principal, and a duty of care when acting on behalf of the principal. ${ }^{1}$ Accordingly, both you and the law would expect the agent under such a fiduciary instrument to manage the principal's affairs prudently, thoughtfully, and carefully, and the law would enforce that expectation with stiff penalties. The same expectation, again backed up by the threat of stiff legal sanctions, holds across an entire family of fiduciary relationships, such as child/guardian, businessperson/factor, and corporation/officer. A fiduciary's duty of care is one of the most basic principles of agency law.

It is also one of the most basic principles underlying the United States Constitution. While all of the prior examples of fiduciary obligations refer to private law rather than public law, the law of agency is very pertinent - and, indeed, crucial - to understanding the relationship between the United States government and the people over whom it exercises jurisdiction.

Federal officials, from the President to members of Congress to federal judges, receive constitutionally delegated discretionary authority over a wide range of subjects. The constitutional text allocates various powers to governmental actors, and it prescribes mechanisms of oversight and supervision of those actors ranging from elections to impeachment proceedings. The document, however, does not generally describe in any detail the manner in which discretionary authority must be exercised. Nonetheless, as a matter of the Constitution’s original

\footnotetext{
* Philip S. Beck Professor, Boston University School of Law; glawson@bu.edu. This article could not have been written without the pioneering work of Robert G. Natelson, from whom we have learned. Portions of this article adapt material from Chapter 7 of a book that is forthcoming from the University Press of Kansas. See GARY LAWSON \& GUY SEIDMAN, “A GREAT POWER OF ATTORNEY”: UNDERSTANDING THE FiDUCIARY CONSTITUTION (2017) (forthcoming). We are grateful to the University Press of Kansas for permission to draw upon that material.

** Professor of Law, The IDC Herzliya, Israel; gseidman@idc.ac.il.

1 See generally TAMAR FRANKEL, FIDUCIARY LAW (2011).
} 
meaning, ${ }^{2}$ all federal powers must be implemented with the thoughtfulness, care, and prudence that would be required of a private-law fiduciary in analogous circumstances. Translating that fiduciary duty into ordinary language: All exercises of federal power must be reasonable. This conclusion does not derive from the Fifth Amendment's Due Process Clause, which as an interpretative matter simply cannot sustain any such load, or indeed from any other specific constitutional provision. It derives instead from the very nature of the Constitution. In a forthcoming book from the University Press of Kansas entitled “A Great Power of Attorney": Understanding the Fiduciary Constitution ${ }^{3}$, we demonstrate at length that the Constitution is most accurately viewed, for purposes of its interpretation, as a kind of fiduciary instrument -- and specifically as a "great power of attorney,” to use the language of the foundingera giant James Iredell. ${ }^{4}$ The legal maker of the Constitution, identified in the Preamble as "We

2 By "original meaning," we mean the communicative signals intended to be conveyed by the Constitution's legal author, who is identified by the document itself as the hypothetical entity "We the People." See Gary Lawson, Reflections of an Empirical Reader (or, Could Fleming Be Right this Time?), 96 B.U. L. REV. 1457 (2016); Gary Lawson \& Guy Seidman, Originalism as a Legal Enterprise, 23 CONST. COMMENTARY 47 (2006). As an operational matter, that intention effectively translates into the meaning that would have been attributed to the document by a hypothetical reasonable observer at the time of the document's making. See Lawrence B. Solum, Intellectual History as Constitutional Theory, 101 VA. L. REV. 1111, 1119, 1136 (2015). We do not claim that original meaning must be the only, or even a relevant, determinant of real-world decisions. That is a claim concerning adjudicative theory, and our claims are limited solely to interpretative theory. On the crucial but oftoverlooked distinction between interpretative theory (what a document means) and adjudicative theory (how decisions regarding a document should be made), see Gary Lawson, Originalism without Obligation, 93 B.U. L. REV. 1309 (2013); Gary Lawson, On Reading Recipes .. . and Constitutions, 85 GEO. L. REV. 1823 (1997). Moreover, we do not claim that fiduciary theory provides insights into real-world decisions as a matter of positive political theory or normative grounding for government as a matter of normative political theory. See Seth Davis, The False Promise of Fiduciary Government, 89 Notre DAME L. REV. 1145 (2014) (identifying many problems with using fiduciary theory as a normative foundation for real-world decisions); Ethan J. Leib \& Stephen R. Galoob, Fiduciary Political Theory: A Critique, 125 YALE L.J. 1820 (2016) (same). Our claims, as we have said, strictly concern the communicative meaning of a specific eighteenth-century document. We speak as lawyers, not as moral or political theorists.

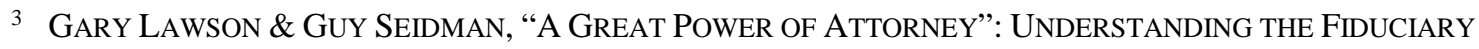
CONSTITUTION (2017) (forthcoming).

44 The Debate in the State Conventions on the Adoption of the Federal Constitution 148-49 (Jonathan Elliot, ed. 2d ed., 1907) (statement of James Iredell) ("[The Constitution] is a declaration of particular powers by the people to their representatives, for particular purposes. It may be considered as a great power of attorney, under which no power can be exercised but what is expressly given”) (emphasis added). 
the People, ${ }^{\circ 5}$ entrusted management of some portion of its affairs to various specified agents, who must exercise their power on behalf of the designated beneficiaries who the Preamble identifies as We the People and its "posterity." ${ }^{\prime}$ In the book, we show that the case for viewing the Constitution as some species of fiduciary instrument is overwhelming. From classical theory, with which all educated members of the founding generation would have been familiar, through English country-party thought to founding-era republicanism, a fiduciary conception of government infused late eighteenth-century political and legal thought. The principal drafters of the Constitution - the members of the Committee of Detail - were private-law lawyers (Oliver Ellsworth, Edmund Randolph, John Rutledge and James Wilson) familiar with drafting agency instruments and a businessperson (Nathaniel Gorham) familiar with applying them. ${ }^{7}$ The general public in that era was far more acquainted with fiduciary instruments than is the general public today. The more one looks at founding-era fiduciary documents, the more one sees them reflected in the United States Constitution.

There were many kinds of eighteenth-century agency instruments, including powers of attorney and corporate charters, from which provisions of the Constitution could have been - and rather clearly were - drawn. In the book, we argue that there is a stronger case for seeing the Constitution as akin to a power of attorney than for seeing it as some other kind of fiduciary instrument, such a corporate charter, though that case is considerably less decisive than is the

5 U.S. CONST. Preamble.

6 Id. ("We the People of the United States in Order to form a more perfect Union, to establish Justice, insure domestic Tranquility, provide for the common defense, promote the general Welfare, and secure the blessings of Liberty to ourselves and our Posterity, do ordain and establish this Constitution for the United States of America").

7 For an enlightening account of the work of the Committee of Detail, see William Ewald, The Committee of Detail, 28 CONST. COMMENTARY 197 (2012). For an account of the familiarity of the Committee with agency law, see Robert G. Natelson, The Framing and Adoption of the Necessary and Proper Clause, in GARY LAWSON, Geoffrey P. Miller, Robert G. NATElson \& Guy I. Seidman, The Origins of the NECESSARY AND Proper CLAUSE 84, 85-86 (2010). 
case for seeing the Constitution in agency terms broadly construed. We also show that once the Constitution is seen in general agency terms, the background rules for ascertaining the meaning of the document must be drawn, at least in large measure, from agency law. How one interprets ${ }^{8}$ a document depends on what kind of document one is interpreting. An agency-law instrument is best interpreted in light of agency law, just as a poem is best interpreted in light of the conventions associated with poetry and a shopping list is best interpreted in light of the conventions typically employed by the author of the shopping list.

This article takes those demonstrations of the fiduciary character of the Constitution and the implications of that character for discerning the Constitution's meaning as jumping-off points and explores one specific but crucial interpretative consequence of viewing the Constitution in fiduciary or agency-law terms. Put simply: If agency-law instruments entail that agents are bound by a duty of care, and if the Constitution is best seen as an agency-law instrument of some kind, then constitutional agents are bound by duties of care. The conclusion, we think, would have been obvious to a reasonable eighteenth-century audience.

For purposes of this article, it does not matter whether one analogizes the Constitution to a power of attorney, a corporate charter, or any other specific kind of fiduciary instrument (though that distinction might very well matter in other contexts). If the Constitution is best understood and interpreted as any kind of agency instrument at all, it follows inexorably that there are unenumerated but nonetheless constitutionally grounded limitations on virtually all of the authority exercised by governmental actors. Those constraints affect the manner in which those powers must be exercised, and they determine on whose behalf the exercise must take place.

8 We use the word "interpret" to mean "ascertain the intended meaning of." It is possible to use the word "interpret" in other fashions, but we limit our use strictly to the positive ascertainment of communicative intentions. 
Understanding the Constitution as a species of agency instrument provides at least an outline for understanding how and why these constraints are present. When agents receive delegated authority, they receive that authority subject to a set of presumptive legal obligations to exercise their authority in a certain way and on behalf of certain beneficiaries. Acceptance of the role of agent, as understood in founding-era English common law, entailed a commitment to provide service to the principal. Agents cannot use their power as they please, because the power is not really their own; they are legally constrained by the very fact that they are acting as agents, not in their personal capacities as private individuals. The agents' duties of, inter alia, care and loyalty form part of the background law of agency, and those duties will govern relationships created by any particular agency instrument unless there is something in the instrument that says otherwise. Nothing in the Constitution says otherwise.

Modern law, to a modest extent, recognizes this overarching requirement of reasonableness in federal action, but it tends to locate it in the textually unpromising interstices of the Due Process Clause and it does not necessarily calibrate the requirement of reasonableness to the precise duty of care that the Constitution actually contemplates. Under the rubric of “substantive due process," all federal legislation must meet a minimum requirement of rationality, though that minimum is so low that any imaginable rationale is considered sufficient to sustain federal action unless the action implicates some judicially favored interests. ${ }^{9}$ Under a fiduciary understanding of the Constitution, the standard of care may well require more than what passes for rationality under modern law, that standard does not necessarily vary with the character of the interest involved, and the standard of care applies to all institutions of the

9 See infra notes 74-78 and accompanying text. 
national government and not simply to Congress. The Constitution's rationality requirement runs far deeper than modern law acknowledges.

In this article, we consider the duties of care required by the Constitution of the President, the federal courts, and Congress when those agents carry out their delegated tasks. We devote most of our attention to Congress, partly because we have at least indirectly explored the duties of the President and the federal courts elsewhere ${ }^{10}$ and partly because the congressional duty of care presents the best vehicle for considering the scope of that duty of care. It is one thing to say that people have a certain duty; it is quite another to say what that duty requires. Because fiduciary duties vary widely with context and circumstances, there are strict limits to the degree of specificity that any such inquiry can yield. But drawing on principles of eighteenth-century fiduciary and corporate law, we can at least begin to flesh out the extent to which the Constitution's very character purports to constrain the discretion of federal actors.

\section{The President's Duty of Care}

The President of the United States presents perhaps the most obvious case for construing constitutionally vested powers in light of background principles of fiduciary law. All federal (and state) officials must "be bound by Oath or Affirmation, to support this Constitution," 11 but only the President has the precise content of the oath specified in the Constitution: The President must swear an oath saying: "I will faithfully execute the Office of President of the United States, and will to the best of my Ability, preserve, protect and defend the Constitution of the United

10 Gary Lawson \& Guy I. Seidman, Necessity, Propriety, and Reasonableness, in LAWson, MiLler, NATELson \& SEIDMAN, supra note 7, at 120.

11 U.S. CONST. art. VI, cl. 3. 
States." 12 Fiduciary duties, of both loyalty ("faithfully) and care ("to the best of my Ability"), are reflected in the constitutionally required oath of office. Accordingly, the President must exercise all of his powers as must any other agent: with regard to the best interests of the beneficiary (in this case We the People and its posterity), with impartiality among multiple beneficiaries (as we have detailed elsewhere ${ }^{13}$ ), and with due care. These are constitutional obligations to the extent that the Constitution is an agency instrument that incorporates general background rules of agency. ${ }^{14}$

The idea that executive officers, such as the President, might be constitutionally bound to exercise due care, loyalty, and impartiality in the exercise of their functions is not, or should not be, at all a startling conclusion. We have previously reached essentially that same result through a different path than we pursue here, ${ }^{15}$ though in the end the two paths converge. The privatelaw background of agency that informs the Constitution elegantly dovetails with a related publiclaw background of obligations, such as those of due care, which we here summarize only briefly. Through that public-law background, which began at least almost two centuries before the Constitution was ratified, some basic principles of agency law were finding their way into the legal norms regarding governmental administration.

By the time of the framing of the Constitution, there was a substantial body of English administrative law governing delegations of power to governmental bodies. One of the most basic principles underlying this law was the notion that grants of discretionary authority to

\footnotetext{
12 Id. art. II, § 1, cl. 7 (emphasis added).

13 Gary Lawson, Guy Seidman \& Robert G. Natelson, The Fiduciary Foundations of Federal Equal Protection, 94 B.U. L. REV. 415 (2014).

14 When and whether constitutional violations of the duty of care are impeachable offenses is a separate question that would require another article. We note the issue without resolving it.

15 See Lawson \& Seidman, supra note 10.
} 
executive agents had to be exercised reasonably, even when that requirement was not spelled out in the grant.

This principle regarding the reasonable exercise of delegated governmental power is typically traced to the 1598 decision in Rooke's Case. ${ }^{16}$ A statute gave sewer commissioners the power to assess landowners for the costs of repairing water-control projects as the commissioners "shall deem most convenient to be ordained." ${ }^{17}$ The commissioner used this statute to assess the full costs of a repair on a single landowner, even though other landowners were also benefited by the project. The court ruled for the assessed landowner because "notwithstanding the Words of the commission give Authority to the commissioners to do according to their Discretions, yet their Proceedings ought to be limited and bound with the Rule of Reason and law. For Discretion is a Science or Understanding to discern between Falsity and Truth, between Wrong and Right, between Shadows and Substance, between Equity and colourable Glosses and Pretences, and not to do according to their Wills and private Affections ....”18 Executive discretion, even when textually unlimited, had to be exercised reasonably and in a disinterested and impartial fashion.

Other decisions applied a similar principle regarding exercise of even very broadly worded grants of discretion in statutes. In Keighley’s Case in 1609, a statute authorizing a sewer commissioner to make rules "after your own wisdoms and discretions" was held to require the agent to exercise discretion "according to law and justice." ${ }^{19}$ Other cases extended the principle

\footnotetext{
165 Co. Rep. 99b (1598). On Rooke's Case as the foundational authority for the interpretation of delegated powers, see WILLIAM WADE \& CHRISTOPHER FORSYTH, ADMINISTRATIVE LAW 293-94 (10 ${ }^{\text {th }}$ ed, 2009).

1723 Hen. 8, c. V, § 3, cl. 3 (1531).

185 Co. Rep. at 99b.

19 See Keighley’s Case, 10 Co. Rep. 139a, 140a (1609).
} 
beyond sewer commissions to include all power delegated by statute. Estwick v. City of London $^{20}$ stated in 1647 that "wheresoever a commissioner or other person had power given to do a thing at his discretion, it is to be understood of sound discretion, and according to law."21 This constraint on the exercise of delegated executive power, which in England eventually came to be called the principle of reasonableness, was firmly established by the end of the seventeenth century. ${ }^{22}$

The principle of reasonableness in the exercise of delegated power was powerfully reiterated on the eve of the founding in 1773 in Leader v. Moxon. ${ }^{23}$ Paving commissioners, under a statute giving them power to pave or repair streets "in such a manner as the commissioners shall think fit," ordered a road repair that effectively buried the doors and windows of plaintiff's house. In awarding damages to the homeowner, the court wrote that the agents "had grossly exceeded their Powers, which must have a reasonable construction. Their Discretion is not arbitrary, but must be limited by Reason and Law.”24 The court explained: "[T]he Act could never intend that any of the Householders should . . . have their Houses buried under Ground, and their Windows and Doors obstructed .... [H]ad Parliament intended to demolish or render useless some houses for the Benefit or Ornament of the rest, it would have given express Powers for the Purpose, and given an Equivalent for the loss that Individuals might have sustained thereby." 25

\footnotetext{
20 Styles 42 (1647).

21 Id. at 43 (emphasis added).

22 See Stanley De Smith et Al, Judicial ReView of Administrative Action 297-98 (5 $5^{\text {th }}$ ed. 1995).

232 W. Bl. 924 (1781).

24 Id. at $925-26$.

25 Id. at 926.
} 
These implicit constraints on governmental discretion were simply part of what it meant to exercise delegated public power. According to these cases, discretion in governmental actors must be exercised impartially (Rooke's Case; Keighley’s Case), with attention to causal efficacy (Keighley's Case), in a measured and proportionate fashion (Leader v. Moxon), and with regard for the rights of affected subjects (Leader v. Moxon). ${ }^{26}$

To be sure, in English law the King (and Queen) had a special status - the royal prerogative -- that created considerable ambiguity about the extent to which these norms applied to him (and her), and more importantly about the extent to which various remedial mechanisms applied in the event that one of the King's subjects suffered legal wrong as a result of executive action (or inaction). One of us has canvassed at length the shifting understandings of royal accountability in England from Magna Carta through the eighteenth century, ${ }^{27}$ and we cannot rehearse that extensive discussion here. Suffice it to say that we are aware of very little support for extending to the American presidency a strong immunity from responsibility for official misfeasance or nonfeasance. Indeed, the fact that the Constitution specifically contemplates impeachment and removal from office not only of subordinate executive officials, as was the case in England, but also of the chief executive himself, ${ }^{28}$ which English law did not recognize, makes clear that at least some of the legal norms governing executive behavior bind the President. We do not need to discuss here the remedies for executive misfeasance, such as

\footnotetext{
26 See Lawson \& Seidman, supra note 10, at 120, 137-41 (elaborating the substantive requirements of reasonableness contained in these cases).

27 Guy I. Seidman, The Origins of Accountability: Everything I Know about the Sovereign's Immunity, I Learned from King Henry III, 49 ST. LOUIS L.J. 393 (2005).

28 U.S. CONST. art. I, § 4.
} 
whether a writ of mandamus will properly lie against the President. ${ }^{29}$ It is enough for us to say that the President is not above the law and to move on, leaving questions of enforcement mechanisms (if any) to another day.

Accordingly, when the federal Constitution vested "executive Power" in the President, ${ }^{30}$ that grant of power carried with it the principle of reasonableness in its implementation as a background principle of interpretation. Crucially, the requirements of the principle of reasonableness, as those requirements would have been understood in the late eighteenth century, are a good proxy for basic fiduciary duties of loyalty, care, and impartiality. That is not surprising. Given the powerful tradition in English and American law of viewing government in fiduciary terms, which is detailed at great length in our book and elsewhere, ${ }^{31}$ there is every reason to think that the principle of reasonableness in English administrative law is simply agency law applied to a governmental context in which the actual instruction or will of the principal is difficult to ascertain but the general sentiment in favor of "proper" and "reasonable" conduct is easier to grasp. Whether one calls it fiduciary duty or the principle of reasonableness, the result is the same: While the President, as with any agent, has a range of choices in the means used to carry out constitutionally assigned tasks, the choice is limited by background principles that render some means of law execution off-limits. As we have said elsewhere: "Could the president, exercising discretion in the selection of forms and means of law enforcement, apprehend a suspect holed up in Concord by leveling the entire town ... ? Could the president in 1790, prior to ratification of the Fourth Amendment, exercise discretionary investigative

29 Mississippi v. Johnson, 71 U.S. (4 Wall.) 475 (1868) (saying “no”).

30 U.S. Const. art. II, § 1, cl. 1.

31 See Robert G. Natelson, Judicial Review of Special Interest Spending: The General Welfare Clause and the Fiduciary Law of the Founders, 11 TEX. REV. L. \& POL. 239 (2007); Robert G. Natelson, The Constitution and the Public Trust, 52 BufF. L. REV. 1077 (2004). 
powers by indiscriminately searching an entire region? We think that all of these measures would be not merely ill-advised, but unconstitutional.”32

The key point is that agency law, developed in English private law and then applied by England's royal courts to public agents as well, suggests serious legal limits on the manner in which the Constitution expects executive agents to carry out their tasks. It also suggests that when engaging in permissible sub-delegation, the President must exercise due care in the selection of sub-agents as well as in the decision to sub-delegate in the first place. The power to sub-delegate, after all, is not a duty to sub-delegate. If the task is best done by the agent personally (where "best" incorporates the idea of opportunity costs), then the agent must personally perform the task. That is not simply wise administrative policy. It is constitutional law.

We thus think that there is a sound foundation in the fiduciary character of the Constitution for something resembling Gillian Metzger's elaboration of a constitutional duty of presidential supervision of subordinates. ${ }^{33}$ Professor Metzger correctly points out that modern law and scholarship tend to focus on questions of the President's right to supervise subordinates rather than questions of the President's duty to supervise. ${ }^{34}$ Even if one cannot derive that duty directly from provisions such as the Take Care Clause ${ }^{35}$ and the Oath Clause, ${ }^{36}$ the fiduciary character of the Constitution and the accompanying fiduciary character of the grant of executive

32 Lawson \& Seidman, supra note 10, at 132-33.

33 See Gillian E. Metzger, The Constitutional Duty to Supervise, 124 YALE L.J. 1836 (2015).

34 See id. at 1875.

35 U.S. CONST. art. II, § 3 ("he shall take Care that the Laws be faithfully executed”).

36 See supra notes 11-14 and accompanying text. For arguments that one can indeed derive such a duty from those provisions, see Metzger, supra note 30, at 1875-78; David M. Driesen, Toward a Duty-Based Theory of Executive Power, 78 Fordham L. REV. 71, 83-87 (2009). We do not disagree with these arguments. We simply maintain that they are subsumed under, and superseded by, the more basic point about the fiduciary character of the Constitution. 
power to the President are sufficient to provide a constitutional foundation for viewing the President as a constrained agent rather than a free actor.

None of that says, of course, what the President's duty of care entails in specific circumstances. As we have intimated, there may not be a general answer to that kind of question, given the contextual character of agency relationships. ${ }^{37}$ We will say more about the broad outlines of a constitutionally grounded fiduciary duty of care when we get to Congress shortly.

\section{Federal Judges’ Duty of Care}

What about federal judges? Are they also subject to fiduciary duties because they exercise a delegated "judicial Power" ${ }^{38}$ ? Of course they are. Other scholars have tried to use agency theory to formulate a general theory of judging in the American political order, ${ }^{39}$ but we are not going that far. We are only trying to interpret the meaning of the "judicial Power" in the context of the federal Constitution. And in that context, agency law has much to say:

Suppose that a federal judge exercises his or her delegated power to decide a case by consulting an Ouija board. The judge's decision could certainly be reversed on appeal. The judge could certainly be impeached and removed by Congress. But more profoundly, the judge has violated the Constitution. There is nothing in Article III that expressly says that judges must decide cases rationally or sensibly, but given the eighteenth-century background norms regarding delegated

\footnotetext{
7 Accord: Metzger, supra note 33, at 1901.

38 U.S. CONST. art. III, § 1.

39 Ethan J. Leib, David L. Ponet \& Michael Serota, A Fiduciary Theory of Judging, 101 CAL. L. REV. 699 (2013).
} 
governmental power, there would be no need for such a specification. Courts are delegated the judicial power, which includes as a necessary element the discretionary power to choose a decision-making methodology. It would simply be taken as given by a founding-era reasonable observer that the delegation to the courts, although seemingly without any internal textual limit, carries the implicit requirement that the power be exercised reasonably. There is substantial room within that grant of power for different methodologies, and even substantial room for error that does not rise to a constitutional violation, but at some point a judgment falls so far off the map that it simply ceases to be an exercise of the judicial power. Put another way: Not everything done by a judge, even in the guise of deciding a case, is an exercise of judicial power (or jurisdiction) within the meaning of Article III. The limits may be broad, but there are limits. ${ }^{40}$ As we noted above, Ethan Leib, David Ponet, and Michael Serota have argued that all American judges, both state and federal, are subject to basic fiduciary duties, and they have sought to derive a robust theory of proper behavior from the nature of the judicial role as established in England and the North-American colonies (if not more widely). They seek to identify "fiduciary duties that . . . are widely applicable to all judges." ${ }^{\prime 1}$ We do not disagree with their general characterization of the role of judges; after all, until fairly recently in AngloAmerican legal history judges were considered a kind of executive official, and we have just seen that there is a long tradition of holding executive officials to fiduciary standards. We agree that fiduciary principles are a powerful way in which to ground familiar ideals of judicial

\footnotetext{
40 Lawson \& Seidman, supra note 10, at 132.

41 Leib, Ponet \& Serota, supra note 39, at 730.
} 
impartiality ${ }^{42}$ and responsibility. ${ }^{43}$ We are less persuaded that one can derive a judicial duty of "deliberative engagement" with the public. ${ }^{44}$ Federal judges are charged with a very specific task - deciding cases or controversies in accordance with governing law - and it is far from obvious how deliberative engagement uniformly promotes that task. But in this article we do not claim principles beyond those that we have identified here as applicable to federal judges by virtue of their constitutional office. Such principles may well exist, but we do not claim them here. And again, the scope of the appropriate duty of care requires more explanation.

We shall now see, in the context of Congress, how much guidance one can draw about that duty from background principles of agency law.

\section{Congress's Duty of Care}

The principle of reasonableness in English administrative law applied to agents exercising authority delegated from Parliament, but Parliament itself was not bound by that principle because Parliament did not exercise delegated authority; it was supreme. "Indeed, the law imposed no substantive limits, of reasonableness or otherwise, on the legislative supremacy of Parliament, which stood above the other two governmental departments in the legal hierarchy." 45

\footnotetext{
42 Id. at 731-33.

$43 \quad$ Id. at 736-39.

44 Id. at $740-52$.

${ }^{45}$ Lawson \& Seidman, supra note 10, at 134-35 (footnote omitted).
} 
Under the American Constitution, however, Congress exercises delegated authority just as does the President and the federal judiciary. Once it is seen that the Constitution is fundamentally an agency instrument, there is no reason to exempt some of the designated agents from the background norms that accompany agency instruments absent some specific provision in the instrument that explicitly overrides those background norms. Accordingly, it is evident that Congress is also bound by a duty of care when it exercises discretionary authority. If an agent is charged with managing or spending another person's money, of course the agent must exercise due care when dealing with those assets. Congress manages money - a staggeringly enormous amount of money - on behalf of We the People and its posterity. The idea that Congress has a duty of care when executing that task, and its other constitutionally delegated tasks, is almost too elementary to articulate.

Put in interpretative terms: All of the power grants in the Constitution come with an implicit coda to the effect of: "to be exercised in a reasonable fashion in accordance with basic fiduciary norms.” The fiduciary duty of care is part of the interpretative background of the document. The real question for us concerns the scope and content of that duty. ${ }^{46}$

In our forthcoming book, we spend considerable energy discussing whether the Constitution is best seen as a kind of power of attorney or as some other kind of fiduciary instrument, such as a corporate charter. There are strong similarities between the Constitution and corporate charters of the eighteenth century, so we readily concede that the case for viewing the Constitution in corporate terms is quite powerful ${ }^{47}$ (though in the end we think less powerful

\footnotetext{
46 Others may be equally or more interested in the mechanisms, if any, by which those duties are enforced. Expulsion? Judicial review? Electoral results? We do not address those potentially important questions of institutional governance in this article.

47 For enlightening expositions of that case in various contexts, see Mary Sarah Bilder, The Corporate Origins of Judicial Review, 116 YALE L.J. 502 (2006); Eric Enlow, The Corporate Conception of the State and the Origins of Limited Constitutional Government, 6 WASH. U. J.L. \& PUB. POL’Y 1 (2001); Geoffrey P. Miller, The Corporate
} 
than the case for viewing it as a power of attorney). It is an intriguing question whether the precise characterization of the Constitution as a specific kind of fiduciary instrument might make a difference in the content of the norm of due care. In the end, we think that it most likely does not matter, but the considerations involved are subtle enough to warrant a close look, especially as those considerations point towards the appropriate standard of care that is incorporated into the Constitution as a background rule of interpretation.

Suppose that one thinks that the Constitution can be analogized to a corporate charter. In that case, one might reason that agents such as Congress are best viewed as corporate directors who determine the general path of the enterprise (and executive and judicial officials might be analogized to managers, though they might fit the role of directors as well for certain designated tasks). Under basic principles of modern-day corporate law, the directors are subject to fiduciary duties of care, but their exercise of discretionary judgment is evaluated pursuant to the so-called "business judgment rule," in which there is "a presumption that in making a business decision the directors of a corporation acted on an informed basis, in good faith and in the honest belief that the action taken was in the best interests of the company. A hallmark of the business judgment rule is that a court will not substitute its judgment for that of the board if the latter's decision can be 'attributed to any rational business purpose." "48 This suggests that the constitutionally implied duty of care, while quite real, is highly deferential to the extent that such a duty conforms to contemporary practice under corporate law. But from the standpoint of original meaning, contemporary practice is not the place to look for the appropriate duty of care.

Law Background of the Necessary and Proper Clause, in LAWSON, MILLER, NATELSON \& SEIDMAN, supra note 7, at 144.

48 Unocal Corp. v. Mesa Petroleum Co., 493 A.2d 946 (Del. 1985) (citations omitted). For a brief overview of the modern business judgment rule, see Mary Siegel, The Illusion of Enhanced Review of Board Actions, 15 U. PA. J. Bus. L.599, 602-08 (2013). 
One must look instead to eighteenth-century baselines. Would the eighteenth-century duty of care of fiduciaries under corporate law, a power of attorney, or other kind of fiduciary instrument be more constraining than the minimalist modern corporate law standard of care?

This is a much more difficult question to answer than it might at first seem. Our present bottom line is actually that the duty of care that forms an interpretative backdrop for understanding all constitutionally vested powers is in fact approximated reasonably well by the modern business judgment rule. It is possible for decisions of governmental actors to be so far outside the normal range of discretion that they amount to a breach of this bedrock fiduciary duty, but the standard is much more forgiving than one of simple error, and it probably does not even reach the "prudent person" standard that modern fiduciary law would likely apply to a wide range of contemporary agency relationships. But, as we will shortly see, that does not necessarily make the standard equivalent to so-called "rational basis" analysis under current constitutional doctrine. The business judgment rule, today and in the eighteenth century, is highly deferential, but it is not a free pass.

Start with the eighteenth-century duty of care of fiduciaries outside of the corporate setting. The law in that regard seems to have been relatively thin. Partly that is a function of the splintered character in earlier times of what today we call fiduciary law, which did not exist as a unified, unitary body of doctrine in the founding era. Executors, guardians, and factors, for example, each had their own standards to meet, and generalizing across those standards is difficult, in part because cases are likely to turn on the language of particular instruments and the specific facts presented.

Professor Robert Natelson has studied this question of founding-era fiduciary standards for far longer and in far more depth than have we, and he concludes regarding the common 
threads among the various eighteenth-century understandings of duties of care: "The 'reasonable man' standard seems not to have been in use yet, but the duty was expressed as an obligation not to neglect the business nor to be guilty of 'folly or negligence’ or, in some cases, as an obligation to avoid ‘supine’ or 'extreme’ negligence or crassa neglegentia (gross negligence). If a fiduciary acted in an 'unreasonable or indiscrete' way, a court . . . also could hold fiduciaries liable . . . .49 This relatively deferential standard actually makes a great deal of sense for an era in which fiduciaries were often not professionals but were simply ordinary citizens acting as executors, guardians, and the like. ${ }^{50}$ An overly strict standard of care would make serving in those positions very risky, and the social costs of discouraging people from serving in those fiduciary capacities would have been enormous. A “business judgment” rule as a baseline (from which any instrument could, if it so chose, depart in either direction) is an understandable first approximation of a generalized fiduciary standard of care in the eighteenth century.

Was that business judgment norm also the eighteenth-century standard of care for corporate directors and officers, so that the interpretative result would be the same whether one sees the Constitution as a power of attorney or as a corporate charter? ${ }^{51}$ That is an even harder question to answer because there appears to be relatively little founding-era law on the fiduciary duties of corporate directors. The corporation itself was a fiduciary for its owners and was even deemed to hold the stock of its owners as a trustee. The corporate stock was treated, for legal

\footnotetext{
49 Natelson, Judicial Review of Special Interest Spending, supra note 31 at 258-59 (copious footnotes omitted).

50 See Robert G. Natelson, The Legal Origins of the Necessary and Proper Clause, in LAWSON, MILLER, NATELSON \& SEIDMAN, supra note 7, at 52, 56.

51 We are assuming that the standard of care for corporate directors and officers is substantially similar. We gather that this assumption is not as straightforward as it might seem to outsiders to corporate law. See Megan Wischmeier Shaner, Restoring the Balance of Power in Corporate Management: Enforcing an Officer's Duty of Obedience, 66 Bus. LAw. 27, 29 (2010) (indicating that Delaware courts did not equate director and officer fiduciary duties until 2009 and suggesting that the scopes of the relevant duties of care remain uncertain).
} 
purposes, as an asset of the corporation, and the stockholders were beneficiaries of the resulting equitable trust. The idea that the stock actually belongs to the stockholders rather than the corporate entity did not gain broad acceptance until the early nineteenth century. ${ }^{52}$

This conception of the corporation as an owner and trustee came out in 1723 in Child v. Hudson's Bay Co., ${ }^{53}$ in which both the corporation and an outside creditor made claims on the stock of a bankrupt stockholder. The corporation had a by-law stating that if any member (stockholder) of the company incurred a debt to the corporation, the stock was to be used first to satisfy the debt to the corporation. The outside creditor denied that the corporation could, through a by-law, effectively make itself a secured creditor. The court ruled in favor of the corporation: "This is a good bye-law; for the legal interest of all the stock is in the company, who are trustees for the several members . . ."54 Once the company is identified as a trustee, then of course background fiduciary principles come into play. We have, however, found little elaboration of the content of those principles in the corporate law context, especially in regard to the duty of care.

In addition, there was some eighteenth-century authority for imposing fiduciary duties directly on the directors and officers of corporations in their personal capacities. The most illuminating case that we have identified is Charitable Corporation v. Sutton. ${ }^{55}$ The case concerned a massive fraud against the company, which had been created as a lending institution, perpetrated by some of its officers. Thompson, the company's warehouse keeper, was the officer

52 See Samuel Williston, History of the Law of Business Corporations before 1800, 2 HARV. L. REV. 149, 149-50 (1888).

5324 Eng. Rep. 702 (1723).

$54 \quad I d$.

5526 Eng. Rep. 642 (1742). 
at the center of the fraud, which involved issuing loans (often to the officer himself) far in excess of the company's assets. ${ }^{56}$ Thompson had "run away out of the kingdom in order to avoid justice, ${ }^{, 57}$ and the company sought to hold the committee-men, who would be the equivalent of modern directors, liable for the losses. There were allegations of nonfeasance in failing to monitor the situation and for malfeasance in appointing some of the perpetrators to positions of authority. The basic claim of the plaintiffs, as described by the court, was that the defendant committee-men "have been guilty of manifest breaches of trust, or at least of such supine and gross negligence of their duty, and so often repeated, that it will amount to a breach of trust." 58

The court found the committee-men clearly liable for "actual breaches of trust" for several events:

The bye-law prescribes, that when notes were to be issued by the cashier, they should be signed by one of the committee-men, and intended as a check upon the warehouse-keeper and cashier.

Now several notes have been issued, without observing this rule, which is an express contravention of the bye-law.

A registry of pledges was kept, in which an entry is made of the value of the goods pawned: after this was done, a new loan is made upon the same pledge, to the same person, and a reference to the old number in the registry upon every new advance; so that it may be called a pedigree of loans through twenty descents.

\footnotetext{
56 The corporation's charter specifically forbade this kind of fractional-reserve banking. See id. (noting that the corporate charter "restrains the company from banking, unless with notes payable on demand, and confined within the amount of the stock").

57 Id. at 643.

$58 \quad I d$.
} 
Now it is not in the nature of the thing possible to suppose, that the same person wanting to re-borrow could replace the first money lent; and therefore at the out-set was a plain and obvious fraud.

As to the third breach of trust, the committee-men's behavior, with regard to Thompson their warehouse-keeper.

It is such a notorious fraud, or at least gross inattention, to suffer him, who was to set a value on all the pledges, to borrow money upon them himself; that, I shall direct those who shall appear to be guilty of it to make good the loss. ${ }^{59}$ “Gross inattention” in supervision thus amounted to a breach of trust.

Other charges of breach of trust against the committeemen alleged what amounts to mismanagement. The original design of the corporation included an officer "called the surveyor of the warehouse, whose business it was to examine all the pledges taken in by the warehousekeeper.”60 However, “[i]n September 1726, the surveyor of the warehouse was discharged, and there was never any appointed afterwards; so that all the checks upon the warehouse-keeper were taken away." 61 The removal of the mechanism for oversight of Thompson was alleged to be a breach of trust. So was “making several orders to put it in the power of Thompson, Woolley, and Warren, to commit those frauds." 62 Though these "are not so clearly breaches of trust," the court

\footnotetext{
59 Id. at 644.

$60 \quad$ Id. at 642.

61 Id. at 643.

62 Id. at 644.
} 
found that those who "issued out the orders, which invested Thompson, Woolley, and Warren, with such powers" ${ }^{\prime 3}$ would be liable.

Even more interesting are the charges against the committee-men for crassa negligentia, or gross negligence in modern parlance. Those claims were founded on " $1{ }^{\text {st }}$, The committeemen's non-attendance upon their employment. 2dly, Their not observing the bye-law of law of laying the balance of cash regularly before them. 3dly, Not taking any notice of forfeited pledges. 4thly, Never once inspecting the warehouse to see what number of real pledges were there. 5thly, Putting the whole power into the hands of Thompson, Woolley, and Warren.”64 The court determined that "committee-men are most properly agents to those who employ them in this trust, and who empower them to direct and superintend the affairs of the corporation.”65 Accordingly, the committee-men were under a duty of care to the corporation and its owners. But in what reads like an early anticipation of the business judgment rule, the court observed: "Now where acts are executed within their authority, as repealing bye-laws and making orders, in such cases though attended with bad consequences, it will be very difficult to determine that these are breaches of trust. For it is by no means just in a judge, after bad consequences have arisen from such executions of their power, to say that they foresaw at the time what must necessarily happen; and therefore were guilty of a breach of trust.”66 This is a very deferential standard. There is language in the opinion suggesting something a bit less deferential: "By accepting of a trust of this sort, a person is obliged to execute it with fidelity and reasonable

\footnotetext{
$63 I d$.

64 Id. at 644 .

65 Id.

$66 \quad I d$.
} 
diligence ....”67 The ultimate standard, however, was whether "there should appear to be a supine negligence ... [in] not making use of the proper power invested in them by the charter, in order to prevent the ill consequences arising from such a confederacy.”68

Although "[n]o case seems to have arisen in the United States during the period from 1800 to 1830 in which the principles of fiduciary law were applied to the directors or officers of business corporations, ${ }^{69}$ we see no reason to think that American law was materially different from English law in these respects. Professor Dodd, in his extensive study of early American corporate law, had "no doubt that American lawyers and judges of the period with which we are concerned were well aware of the fact that English law had long insisted that persons who act for others in such capacities as agents, partners, trustees, guardians, executors, or administrators must observe a high standard of loyalty to those whose property interests have been entrusted to their charge.,70

The best summary that we can exact from these materials is that eighteenth-century fiduciaries generally, whether attorneys or corporate directors, had a duty of care as a baseline part of their obligations, but that the standard of care that could be legally enforced was akin to a standard of gross negligence. To the extent that the Constitution is a fiduciary instrument, of any plausible kind to which it can be analogized, federal actors must exercise their discretion at least in accordance with this standard.

$67 \quad I d$. at 645.

68 Id.

69 EDWIN MERRICK DODD, AMERICAN BUSINESS CORPORATIONS UNTIL 1860, WITH SPECIAL REFERENCE TO MASSACHUSETTS 70 (1954).

70 Id. 
Interestingly, that conclusion is not very far removed from ideas that are central to modern constitutional law, though modern law does not ground its principles in fiduciary notions or conform to them precisely. The contemporary business judgment rule in corporate law is often cast as a "rational basis" test, in which the decision of a board of directors will be upheld if it "can be attributed to any rational business purpose,"71 though the standard is also sometimes framed as one of "gross negligence," as was the evident eighteenth-century standard. ${ }^{72}$ For students of American constitutional law, the term "rational basis” has immediate resonance.

In 1938, the Supreme Court famously declared that congressional legislation that did not implicate certain judicially-favored interests (which today are generally called "fundamental rights") "is not to be pronounced unconstitutional unless in the light of the facts made known or generally assumed it is of such a character as to preclude the assumption that it rests upon some rational basis within the knowledge and experience of the legislators." ${ }^{73}$ Four years earlier, in a case involving state rather than federal legislation, the Court said: "If the laws passed are seen to have a reasonable relation to a proper legislative purpose, and are neither arbitrary nor discriminatory, the requirements of due process are satisfied."74 The clear implication is that legislation is to be pronounced unconstitutional if it cannot be assumed to rest upon a rational basis or to have a reasonable relation to a proper legislative purpose. That is, the implication is that there is a general background norm of rationality with which any legislation must comply.

\footnotetext{
71 Sinclair Oil Corp. v. Levien, 280 A.2d 717, 720 (Del. 1971).

72 Smith v. Van Gorkom, 488 A.2d 858, 873 (Del. 1985).

73 United States v. Carolene Products Co., 304 U.S. 144, 152 (1938). On the exception for favored rights, see id. at n.4.

74 Nebbia v. People of New York, 291 U.S. 502, 537 (1934). For a brief account of the Supreme Court's rational basis jurisprudence, see Steven Menashi \& Douglas H. Ginsburg, Rational Basis with Economic Bite, 8 N.Y.U. J. L. \& LIBERTY 1055, 1058-60 (2014).
} 
While it may be difficult to find legislation that is so absurd that it will not sustain a presumption of legislative rationality (just as it may be difficult to find business decisions so preposterous that no presumption of responsible judgment can be indulged with respect to them), it is not impossible to do so. The Supreme Court has even found a federal statute refusing to recognize state definitions of marriage that include same-sex couples to be irrational and therefore invalid, ${ }^{75}$ though the case obviously implicated other, more particularized concerns even if the decision did not precisely identify them. Numerous cases announce the rational basis standard while finding it satisfied.

It is very difficult to find a textual hook for this kind of "rational basis review," as it has come to be called. The cases involving action by state officials typically invoke the Equal Protection Clause of the Fourteenth Amendment, but even if that was a plausible ground for such a requirement in the context of state actors, there is no express Equal Protection Clause applicable to the federal government. ${ }^{76}$ Certainly the Due Process Clause of the Fifth Amendment is an unlikely home for it, for reasons that have oft been given about the implausibility of "substantive due process" as an interpretation of the Fifth Amendment. ${ }^{77}$

The background duty of care imposed by fiduciary theory, however, just might fit the bill. Indeed, the eighteenth-century duty of care may even be slightly more rigorous than

75 United States v. Windsor, 133 S. Ct. 2675 (2013).

76 That does not mean that there is no general equality norm applicable to federal action. It just means that such a norm must derive, as does the reasonableness requirement that we discuss here, from the fiduciary character of the Constitution. See Lawson, Seidman \& Natelson, supra note 13.

77 See, e.g., Robert G. NATElson, The Original Constitution: What It ACTUALly SAID AND MEANT 167-70 (2d. ed. 2011); John Harrison, Substantive Due Process and the Constitutional Text, 83 VA. L. REV. 493 (1997); Ryan C. Williams, The One and Only Substantive Due Process Clause, 120 YALE L.J. 408 (2010). As Professor Williams makes clear, see id. at 416, it is possible that there is a stronger case for "substantive due process" as an interpretation of the mid-nineteenth-century Due Process Clause of the Fourteenth Amendment. As we emphasize in our concluding remarks, nothing that we say in this article bears on the meaning of the Fourteenth Amendment. But there is little to be said for such an interpretation of the late-eighteenth-century Fifth Amendment Due Process Clause. 
modern "rational basis" review, though that is hard to glean with any confidence from the eighteenth-century law. The founding-era cases support a fiduciary standard of gross negligence. Modern rational basis inquiry excuses even gross negligence; it allows laws to stand if one can imagine a rationale for them, even if the actors did not actually formulate or rely upon that rationale. Agency law arguable demands a bit more than modern rational basis inquiry provides. In any event, once government actors are seen as fiduciaries of any sort at all, the idea that their actions are entirely unconstrained by law other than express prohibitions in the governing instrument is quite absurd. Any such result would have to come from an explicit statement in a document that the governing background law of fiduciary instruments was superseded. There is nothing in the United States Constitution even resembling such a provision. Substantive due process may well be an oxymoron, and also an implausible interpretation of the Fifth Amendment, but from the standpoint of original meaning rational basis review of federal legislation has a very potent constitutional pedigree. And, as we have seen, the case for imposing such a standard on federal executive and judicial officials is at least as strong. If Congress is bound by fiduciary standards, then a fortiori so are the President and federal judges. The reasonableness requirement of fiduciary law also suggests that there is no good reason to think that executive officials should be held to a lower standard of rationality than are legislators, as modern case law would have it. ${ }^{78}$ Federal actors are all agents, each charged with specific tasks. The nature of the tasks lead to differences in the application of fiduciary standards, but it is far from obvious that some tasks call for a lower standard than others, ${ }^{79}$ just as

78 County of Sacramento v. Lewis, 523 U.S. 833, 846 (1998).

79 See Rosalie Berger Levinson, Time to Bury the Shocks the Conscience Test, 13 CHAPMAN L. REV. 307 (2010). 
it is far from obvious that corporate officers should be subject to a different fiduciary standard than corporate directors.

\section{Conclusion}

The idea that federal governmental action should, as an ideal, be reasonable is not especially controversial. But finding a textually grounded constitutional basis for turning that desideratum into an actual legal norm has been a different story. Once the Constitution is seen as an agency instrument, however, the requirement of reasonableness follows quite easily as a matter of original meaning - not from a specific textual provision but from the nature of the text itself. One does not need the oxymoronic label "substantive due process" to describe this reasonableness requirement. It derives from the basic fiduciary duty of care.

We hasten to add that it is an entirely different question from those that we address here whether state laws or state executive or judicial officials are subject to a constitutionally grounded reasonableness review. Modern law unquestionably subjects state actors to some such standard via the Fourteenth Amendment, but it is not at all clear that this practice is (or is not) constitutionally grounded under our analysis. Because the Constitution does not generally empower state officials and state legislators (with some modest exceptions ${ }^{80}$ ), those actors are not subject to the background fiduciary standards that underlie the federal Constitution when they act within the compass of their state authority. It is possible that their own state constitutions impose those standards, but that is something that would have to be determined on

80 There are a number of contexts, primarily involving federal elections and constitutional amendments, in which state officials get their authority to act from delegations from the federal Constitution. In those limited contexts, fiduciary analysis would apply to state officials to the same extent that it applies to federal officials. 
a state-by-state basis. It is also possible that, while substantive due process is a very tough sell under the Fifth Amendment, it might be a more plausible understanding of the Fourteenth Amendment that was enacted in $1868 .^{81}$

Thus, it is compatible with everything that we have said here to maintain either (1) that there is no general rationality requirement for state action, (2) that there is a general rationality requirement for state action that is equivalent to the requirement for federal action , (3) that there is a general rationality requirement for state action that is stricter than the requirement for federal action, or (4) that there is a general rationality requirement for state action that is less demanding than the requirement for federal action. Choosing among those alternatives involves matters well beyond the scope of our analysis, which is confined to a study of the Constitution of 1788. Our claim here is only that, as a matter of original meaning, some kind of general requirement of reasonableness for federal action, whether cast as a modestly revamped "rational basis” review or as akin to a "business judgment" rule, is a background interpretative norm of the Constitution of $1788 .^{82}$

81 See Williams, supra note 77, at 416.

82 For an argument that is much to the same effect, from a very different interpretative perspective, see Jane R. Bambauer \& Toni M. Massaro, Outrageous and Irrational, 100 MinN. L. REV. 281 (2015). 